\title{
Larval rearing and spat production of Marcia opima (Gmelin)
}

\author{
P. Muthiah*, J.X. Rodrigo, N. Suja \\ Tuticorin Research Centre of CMFRI, 115 N.K. Chetty Street, Tuticorin 628001, India
}

Received 26 March 2001; received in revised form 26 November 2001; accepted 14 January 2002

\begin{abstract}
The 'baby clam' Marcia opima (Gmelin) was spawned on seven occasions in the shellfish hatchery at the Tuticorin Research Centre, India. The fertilized eggs measured $47.8 \mu \mathrm{m}$ in diameter and the straight hinged larvae attained at $20 \mathrm{~h}$ were $87 \mu \mathrm{m}$ in length and $71 \mu \mathrm{m}$ in height. Settlement occurred on day 9 at $273 \mu \mathrm{m}$. The percentage of settlement varied from $13.9 \%$ to $56.2 \%$. The growth of post-set clam spat has been described by the equation of $L=0.0086 x^{1.4672}$, where $L$ is the length in $\mathrm{mm}$ and $x$ is the number of days. The clam seed reached a size of $11.5 \mathrm{~mm}$ at 4 months. The significance of this study is to standardize the techniques for hatchery production of the seeds of M. opima.

(C) 2002 Elsevier Science B.V. All rights reserved.
\end{abstract}

Keywords: Marcia opima; Larval rearing; Spat production

\section{Introduction}

The venerid clam Marcia opima (Gmelin), which has, so far, been indicated as Katelysia opima (Gmelin), is abundantly distributed in the estuaries of the east and west coasts of India (Abraham, 1953; Alagarswami and Narasimham, 1973; Appukuttan et al., 1988). Rao Syda and Meiyappan (1988) estimated $82 \mathrm{t}$ of $K$. opima forming $1.5 \%$ of the clam resources in the estuaries of Dakshina Kannada. Appukuttan et al. (1988) reported a total annual production of $5436.5 \mathrm{t}$ of $K$. opima during 1982-1983 at Ashtamudi estuary. Mane (1974) and Nagabhushanam and Mane (1975) studied the reproductive cycle and breeding habits of $K$. opima in Kalbadevi estuary, Ratnagiri. Thomas and Kizhakudan (1998) reported the abundance of M. opima in Medha creek,

\footnotetext{
* Corresponding author.
} 
Gujarat. For augmenting production, transplantation of seed to suitable areas of Ashtamudi estuaries was suggested by Appukuttan et al. (1988). However, since wild collection of seed is seasonal, the information on the hatchery production of the seed of M. opima will be useful. Nell et al. (1994) attempted rearing of K. rhytiphora in Australian waters. This report details the first successful attempt at larval rearing and large-scale spat production of M. opima.

\section{Material and methods}

Potential broodstock clams of 30-48 mm length were collected from Ashtamudi estuary (latitude $845^{\prime} \mathrm{N}$, longitude $78^{\circ} 28^{\prime} \mathrm{E}$ ) in the west coast and packed in a wet gunny sack, transported by road to the shellfish hatchery in Tuticorin on the east coast (latitude $8^{\circ} 48^{\prime} \mathrm{N}$, longitude $78^{\circ} 11^{\prime} \mathrm{E}$ ). These clams were kept in fiber-reinforced plastic tanks of 100-1 capacity at a temperature of $22-24{ }^{\circ} \mathrm{C}$ with mild aeration. Sand-filtered seawater was changed daily. The clams were provided with a mixed culture of Isochrysis galbana and the diatom Chaetoceros sp. cultured out-of-doors (Nayar et al., 1987). Seven spawnings occurred on 11 January, 2 and 24 February, 2 March, 14 June, 25 July and 23 September 2000 in the hatchery.

On three occasions (11 January, 2 March and 14 June 2000), the adult clams transported from Ashtamudi spawned the next day without inducement. In the rest of the spawnings, 20 clams selected at random from the conditioning tanks were exposed to 32 ${ }^{\circ} \mathrm{C}$ for half an hour. The water temperature in the 100-1 perplex tank in which the clams were kept was raised to $32{ }^{\circ} \mathrm{C}$ by operating a heating element (placed inside a porcelain tube) and controlled by a thermostat. After half an hour of treatment when no spawning had occurred, the clams were transferred to a 100-1 tank receiving filtered, gently aerated seawater $\left(28{ }^{\circ} \mathrm{C}\right)$ in the hatchery. These thermally induced clams spawned the next day. The fertilized eggs and morula were collected in a $40-\mu \mathrm{m}$ sieve and transferred to a larval rearing tank with a 1000-1 capacity after passing through a $100-\mu \mathrm{m}$ sieve to remove debris. Sand-filtered seawater was passed through cotton wool at the delivery end for rearing the larvae and spat. From straight hinged stage, the larvae were fed with I. galbana.

Periodically, 20 larvae from the spawning that occurred on 11 January 2000 were fixed in $1 \%$ formalin and measured with a precalibrated ocular micrometer for length (anterioposterior axis) and for height (dorso-ventral axis). The average of these measurements (with S.D.) is given for larval size and growth stages. The water in the rearing tank was changed on alternate days. The temperature ranged from 28 to $31{ }^{\circ} \mathrm{C}$ and the salinity varied from 34 to $36 \mathrm{ppt}$.

\section{Results}

Embryonic and larval stages were recognized by other bivalve developmental descriptions (Loosanoff and Davis, 1963; Loosanoff et al., 1966; Alagarswami et al., 1983; Narasimham et al., 1988). 

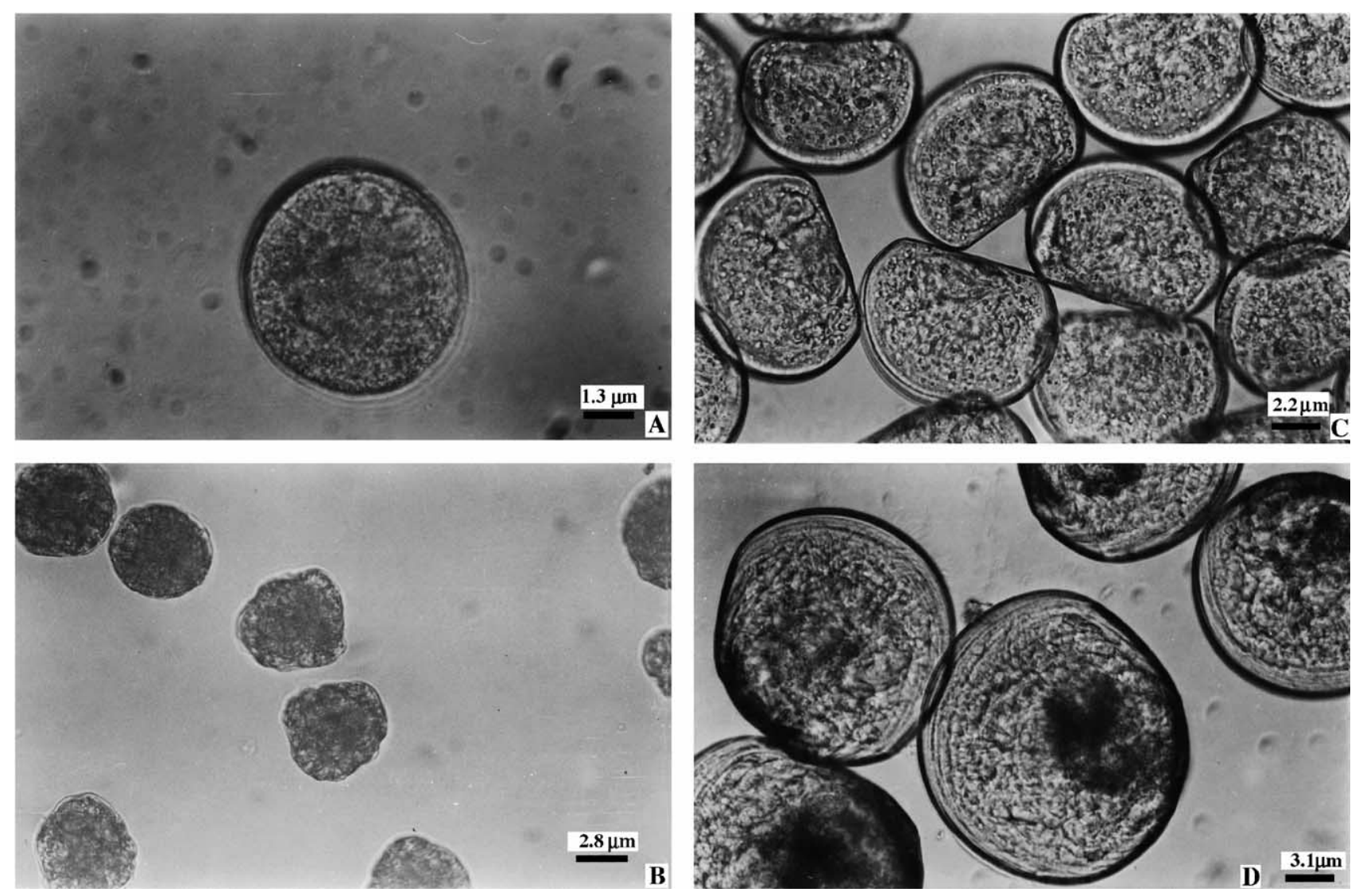

Fig. 1. Larval development of M. opima: (A) fertilized egg; (B) morula; (C) straight hinge stage; (D) umbo. 


\subsection{Larval rearing}

The diameter of the fertilized eggs ranged from 43 to $59 \mu \mathrm{m}(\bar{x}=47.8 \pm 5.1 \mu \mathrm{m})$ (Fig. 1A). Cleavage started $10 \mathrm{~min}$ after fertilization and the morula (Fig. 1B) was $55 \mu \mathrm{m}$ in diameter. Within $20 \mathrm{~h}$, the larvae reached the straight hinged ('D' shaped) stage with a well-developed ciliated velum (Fig. 1C). The average size was $87 \times 77 \mu \mathrm{m}$ $($ S.D. $= \pm 2.7 \times 6.8)$. The larvae were reared at densities varying from 0.2 to 1.2 larvae/ $\mathrm{ml}$. Microalgal food was provided at a concentration of 5000 cells of I. galbana/larva. On day 5 , the early umbo was $115.5 \times 96.8 \mu \mathrm{m}( \pm 8.9 \times 6.6)$, and the advanced umbo on day 7 was $187 \times 169 \mu \mathrm{m}( \pm 16.9 \times 10.8)$ (Fig. 1D). The feeding was increased to 8000 cells/larva. The larvae on day 8 attained a mean size of $214.5 \times 198 \mu \mathrm{m}( \pm 13.7 \times 13.5)$ with a maximum of $231 \times 220 \mu \mathrm{m}$ in length and height, respectively. Settlement started on day 9, and on day 10, the size was $225 \mu \mathrm{m}$. Settlement was completed on day 11 when the size of the larvae was $273 \times 260 \mu \mathrm{m}( \pm 18.3 \times 18.2)$. After settlement, the feeding rate was increased to 10,000 cells/spat. The size of the spat on day 13 was $310 \times 294 \mu \mathrm{m}$ $( \pm 42.6 \times 45.2)$, and on day 16 , the size was $404 \times 375 \mu \mathrm{m}( \pm 95.4 \times 92.4)$.

The relationship between shell length and height of the larvae was linear (Fig. 2) and was described by the following equation

$$
H=-18.272 \times 1.0062 L
$$

where $L$ and $H$ are length and height $(\mu \mathrm{m})$ of the larvae, respectively, with an $r$ value of 0.9947, indicating high significance.

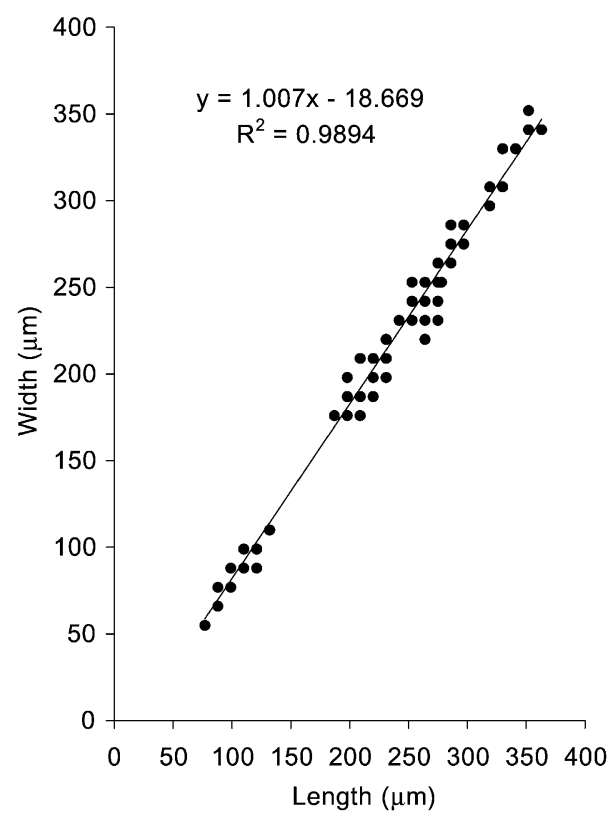

Fig. 2. The relationship between length and height of the larvae of M. opima. 


\subsection{Growth of spat}

On day 18 , the spat were $499 \mu \mathrm{m}( \pm 159.8)$ in length with a maximum size of $737 \mu \mathrm{m}$ (Fig. 3A). The feeding rate was increased to 12,000 cells/spat. On day 23, the maximum and minimum lengths were $1.29 \mathrm{~mm}$ and $510 \mu \mathrm{m}$, respectively, with an average size of 917 $\mu \mathrm{m}( \pm 235)$. On day 29 , the mean size increased to $2.01 \times 1.7 \mathrm{~mm}( \pm 0.2 \times 0.16)$. The feeding rate was increased to 20,000 cells/spat and, along with $I$. galbana, a mixed algal culture was also provided. On day 45, the juveniles attained a maximum of $3.4 \mathrm{~mm}$ and a minimum of $1.7 \mathrm{~mm}$ with an average of $2.38 \mathrm{~mm}( \pm 0.5)$.
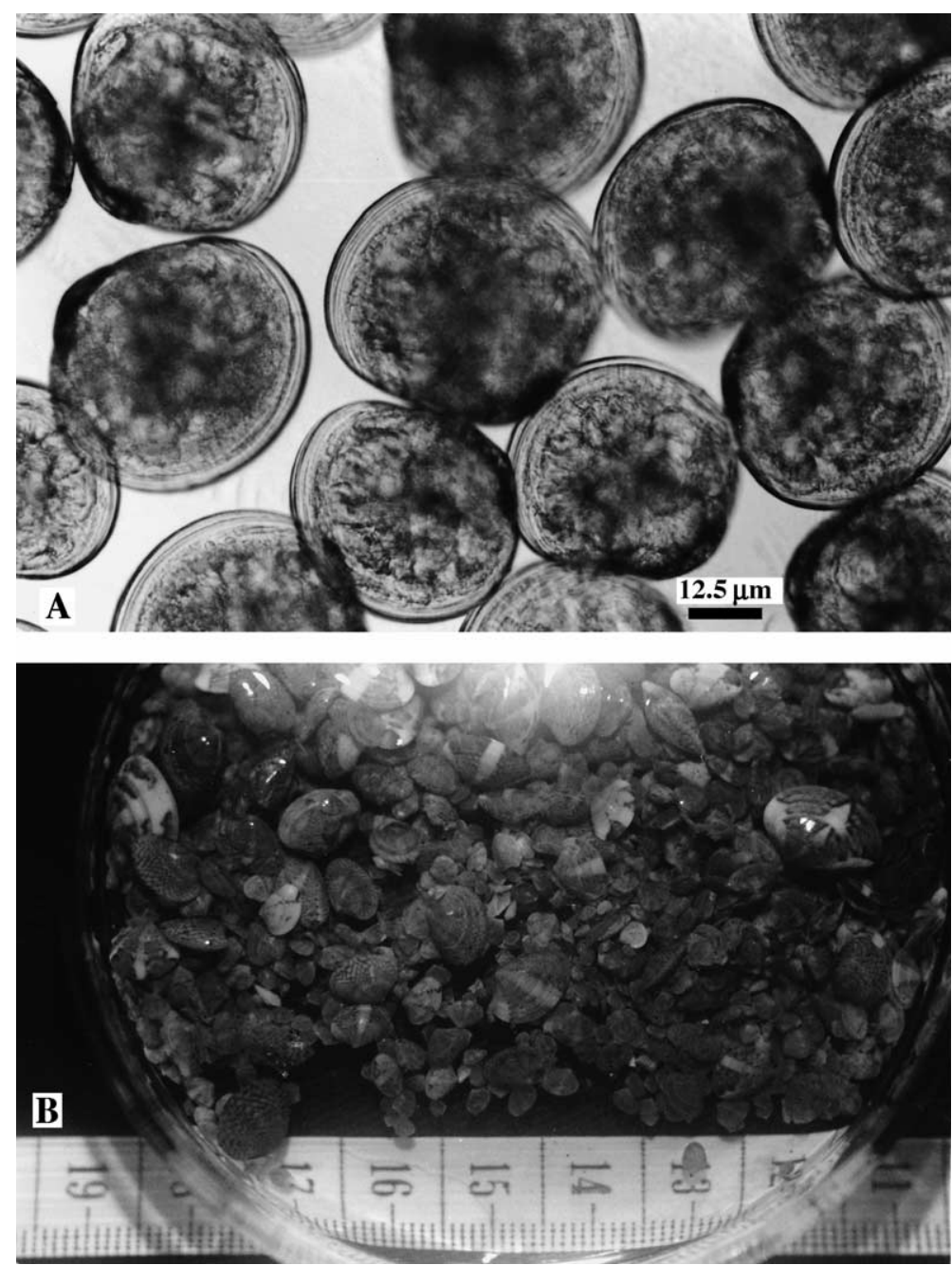

Fig. 3. (A) Spat and (B) juveniles. 


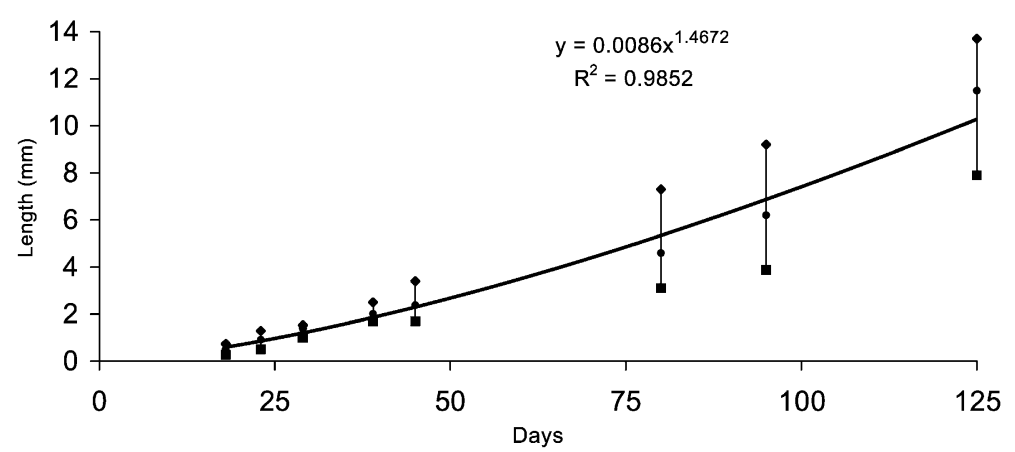

Fig. 4. Growth of the post-set M. opima. The horizontal line represents the length range and the solid circles the mean length. The curve obtained by fitting the growth equation is indicated.

Thereafter, 200 seeds were kept in a $500-\mu \mathrm{m}$ mesh velon screen pouch of $20 \times 18 \mathrm{~cm}$. The pouches were placed in a sand-mud intertidal area and covered with a synthetic twine-netted cage for protection from crab predation. On day 80 , the average size was $4.6 \times 3.7 \mathrm{~mm}( \pm 0.8 \times 0.7)$ and increased to $6.2 \times 4.6 \mathrm{~mm}( \pm 1.3 \times 0.9)$ by day 95 . On day 125 , the length ranged from 7.9 to $13.8 \mathrm{~mm}$ with an average of $11.5 \mathrm{~mm}$ (Fig. 3B). The growth of post-set clams can be described by the equation

$$
Y=0.0086 x^{1.4672}
$$

where $Y=$ length in $\mathrm{mm}$ and $x$ is the number of days with $r=0.9926$, indicating a high degree of significance (Fig. 4).

\subsection{Spat production}

The number of larvae reared from each of the seven spawnings ranged from 40,000 to 576,000 with survival to settlement ranging from $13.9 \%$ to $56.2 \%$ (' $\mathrm{D}$ ' stage to spat). The spawning that occurred on 24 February 2000 resulted in total mortality. The number of spat produced from each spawn ranged from 5,550 to 184,000 (Table 1).

Table. 1

Details of spat production in M. opima

\begin{tabular}{llll}
\hline Date of spawning & $\begin{array}{l}\text { Number of larvae } \\
\text { reared (in thousands) }\end{array}$ & $\begin{array}{l}\text { Number of spat } \\
\text { settled (in thousands) }\end{array}$ & $\begin{array}{l}\text { Percentage of } \\
\text { settlement }(\%)\end{array}$ \\
\hline 11 January 2000 & 130 & 73.00 & 56.2 \\
2 February 2000 & 120 & 48.80 & 40.7 \\
24 February 2000 & 175 & - & - \\
2 March 2000 & 40 & 5.55 & 13.9 \\
14 June 2000 & 576 & 184.00 & 31.9 \\
25 July 2000 & 566 & 144.00 & 25.7 \\
23 September 2000 & 220 & 87.00 & 39.6 \\
\hline
\end{tabular}




\section{Discussion}

Spawning in bivalves is generally influenced by manipulating water temperature. Raising of $5{ }^{\circ} \mathrm{C}$ in summer and up to $10{ }^{\circ} \mathrm{C}$ in winter initiated the spawning of Venus striatula (Ansell, 1961) and a few degrees for Mercenaria mercenaria (Loosanoff and Davis, 1963). In the spawning experiments conducted, the broodstock of M. opima failed to spawn when subjected to thermal stimulation from 24 to $32{ }^{\circ} \mathrm{C}$. When returned to tanks with seawater $\left(28^{\circ} \mathrm{C}\right)$, spawning occurred the next day. Similarly, spawning was obtained by exposing Aequipecten irradians to an initial increase in temperature to $30{ }^{\circ} \mathrm{C}$ and a subsequent decrease in temperature from 27.9 to $22{ }^{\circ} \mathrm{C}$ (Sastry, 1963) and transferring thermally induced Anadara granosa to $24{ }^{\circ} \mathrm{C}$ (Muthiah et al., 1992).

In this study, the larval development was completed within 9 days and settlement occurred on days 9 and 10. Nell et al. (1994) observed settlement of K. rhytiphora at $19{ }^{\circ} \mathrm{C}$, on day 19 . The earlier settlement obtained in this study may be due to higher temperatures of $30-31{ }^{\circ} \mathrm{C}$ in which the larvae were reared. Larvae of M. mercenaria reared at $30{ }^{\circ} \mathrm{C}$ began to set on day 7 , whereas at $18{ }^{\circ} \mathrm{C}$, metamorphosis occurred only after 16 days (Loosanoff et al., 1951). Similarly, Ansell (1961) recorded significant growth rate in $12-22.5{ }^{\circ} \mathrm{C}$ among the larvae of $V$. striatula reared from 5 to $26{ }^{\circ} \mathrm{C}$. Calabrese and Davis (1970) also observed best larval growth at higher temperatures $\left(22-27.5^{\circ} \mathrm{C}\right)$ while testing the larval growth and settlement of the coot clam Mulinia lateralis at temperatures varying from 7.5 to $27.5^{\circ} \mathrm{C}$.

In the larval rearing of $M$. opima, an eyed stage was not observed. Similarly, absence of an eyed stage has been mentioned for the great clam Meretrix meretrix (Narasimham et al., 1988), the coot clam M. lateralis, the venerid clam Pitar morrhuana, the cockle Laevicardium mortoni (Loosanoff et al., 1966) and the mud clam Rangia cuneata (Chanley, 1965).

Although the larvae of $M$. opima from the same brood showed considerable size variation, there was a significant linear relationship between shell length and height of larvae (Fig. 2). Variations in size of the larvae of single brood have also been reported for other bivalves (Loosanoff and Davis, 1963; Alagarswami et al., 1983; Narasimham et al., 1988; Muthiah et al., 1992).

By providing I. galbana alone as food, the larvae metamorphosed on day 9. Calabrese and Davis (1970) indicated that larvae of the hard clam grow more rapidly on a mixture of several species of algae rather than on any single species. Evaluation of an effective mixed diet rather than a single diet for larvae of $M$. opima has to be studied.

During larval rearing, low incidences of larval mortality due to bacteria and fungi in the moribund larvae were noticed. Pseudomonas sp. and Vibrio sp. were reported pathogenic to the larvae of M. mercenaria (Gullard, 1959). Davis et al. (1954) observed the fungus Sirolpidium infection in the larvae of $V$. mercenaria. Hence, in addition to the studies on feed requirements for clam larvae, spat and broodstock and the optimum larval rearing density as envisaged by Narasimham et al. (1988), studies on larval mortality due to diseases caused by bacteria and fungi and appropriate treatment procedures should be initiated.

Since 1981, K. opima has been indiscriminately exploited to meet expanding export markets (Appukuttan et al., 1988). Seed availability is one of the major constraints for 
replenishing the resource or to initiate farming. In this context, the present study provides useful information for developing large-scale seed production of M. opima.

\section{Acknowledgements}

Our sincere thanks to Dr. John Taylor, the National History Museum, London, for identification of the clam. We are thankful to Dr. Mohan Joseph, Director, Central Marine Fisheries Research Institute for encouragement, to Dr. K.K. Appukuttan, Head, Molluscan Fisheries Division, for the keen interest and suggesting valuable improvements in the manuscript and we also extend our thanks to Shri Hameed Batcha and J. Padmanathan, Technical Assistants, for their help.

\section{References}

Abraham, K.C., 1953. Observations of the biology of Meretrix casta (Chemnitz). J. Zool. Soc. India 5, $163-190$. Alagarswami, K., Narasimham, K.A., 1973. Clam, cockle and oyster resources Indian coasts. Proc. Symp. Living Resources Seas Around India. CMFRI Spec. Publ., Cent. Mar. Fish. Res. Inst., Cochin, India, pp. 648-658.

Alagarswami, K., Dharmaraj, S., Velayudhan, T.S., Chellam, A., Victor, A.C.C., 1983. Embryonic and early development of pearl oyster Pinctada fucata (Gould). Proc. Symp. Coastal Aquacult. 2, 598-603.

Ansell, A.D., 1961. Reproduction, growth and mortality of Venus striatula (da Costa) in Kames Bay, Millport. J. Mar. Biol. Assoc. U. K. 41, 191-215.

Appukuttan, K.K., Prabhakaran Nair, K., Thomas, K.T., 1988. Clam resources of the Asthamudi lake, with special reference to Katelysia opima (Gmelin) fishery. CMFRI Bull. 42 (1), 14-20.

Calabrese, A., Davis, H.C., 1970. Tolerance and requirement of embryos and larvae of bivalve molluscs. Helgol. Wiss. Meeresunters. 20, 553-564.

Chanley, P., 1965. Larval development of the brackishwater mactrid clam Rangia cuneata. Chesapeake Sci. 6 (4), $209-213$.

Davis, H.C., Loosanoff, V.L., Weston, W.H., Martin, C., 1954. A fungus disease in clam and oyster larvae. Science 120, 36-38.

Gullard, R.R.I., 1959. Further evidence of the destruction of bivalve larvae by bacteria. Biol. Bull. 117, $258-266$.

Loosanoff, V.L., Davis, H.C., 1963. Rearing of bivalve molluscs. Advances in Marine Biology, vol. 1, pp. 1-136. Academic Press, London.

Loosanoff, V.L., Miller, W.S., Smith, P.B., 1951. Growth and setting of larvae of Venus mercenaria in relation to temperature. J. Mar. Res. 10, 59-81.

Loosanoff, V.L., Davis, H.C., Chanley, P.E., 1966. Dimensions and shapes of larvae of some marine bivalve molluscs. Malacologia 4 (2), 351-435.

Mane, U.H., 1974. Growth and breeding habits of the clam, Katelysia opima in the Kalbadevi estuary at Ratnagiri. Indian J. Fish. 21 (2), 386-398.

Muthiah, P., Narasimham, K.A., Gopinathan, C.P., Sundararajan, D., 1992. Larval rearing, spat production and juvenile growth of the blood clam Anadara granosa. J. Mar. Biol. Assoc. India 34 (1-2), 138-143.

Nagabhushanam, R.B., Mane, U.H., 1975. Reproduction and breeding of the clam, Katelysia opima, in the Kalbadevi estuary at Ratnagiri, west coast of India. Indian J. Mar. Sci. 4, 86-92.

Narasimham, K.A., Muthiah, P., Gopinathan, C.P., Gandhi, A.D., 1988. Larval rearing and spat production of the great clam, Meretrix meretrix (Linnaeus). Indian J. Fish. 35 (2), 107-112.

Nayar, K.N., Rao, K.S., Rajapandian, M.E., Gopinathan, C.P., Gandhi, A.D., 1987. Production of oyster seed in a hatchery system. In: Nayar, K.N., Mahadevan, S. (Eds.), Oyster Culture-Status and Prospectus. CMFRI Bull., 38, pp. 52-58.

Nell, J.A., Wayne connor, A.O., Michael Heasman, P., Lindsay Goard, J., 1994. Hatchery production for venerid 
clam Katelysia rhytiphora (Lamy) and the Sydney cockle Anadara trapezia (Deshayes). Aquaculture 119, 149-156.

Rao Syda, G., Meiyappan, M.M., 1988. Assessment of clam resources in the estuaries of Dakshina Kannada. CMFRI Bull. 42 (1), 20-23.

Sastry, A.N., 1963. Reproduction of the bay scallop Aequipecten irradians Lamarck: influence of temperature on maturation and spawning. Biol. Bull. 125, 146-153.

Thomas, S., Kizhakudan, J., 1998. Note on Marcia opima, a venerid clam from Medha creek, Gujarat. Mar. Fish. Inf. Serv., Tech. Ext. Ser. 158, 16-18. 